\title{
Defective object clitic paradigms and the relation between language development and $\operatorname{loss}^{1}$ \\ SANDRA PAOLI \\ The University of Oxford
}

\begin{abstract}
Through an investigation of morphologically defective pronominal object paradigms in a number of northern Italian dialects, this article offers a reflection on the relation between the development and the loss of linguistic items based on the reconstruction of the possible diachronic path that has led to the current situation. The paper sets out to achieve two objectives: firstly, it presents a detailed description of the peculiarities of the object clitic paradigm in the northern Italian dialects and it places them within the wider Romance context; secondly, it discusses and evaluates the way the processes of emergence and loss of linguistic items relate to one another, with specific reference to what appears to be a more general hierarchy operative in languages, the Referential Hierarchy (Silverstein 1976; Comrie 1981 and many others).
\end{abstract}

\section{INTRODUCTION}

The existence of two sets of pronominal forms, tonic and clitic, is characteristic of the Romance languages. The clitic series has been the subject of extensive descriptive and theoretical work, traditionally focusing on such issues as the nature of clitic forms, clitic placement (specifically, movement versus base-generation), clitic clusters and ordering within them, clitic climbing (and restructuring phenomena), clitic doubling and the pursuit 
of a unified account of clitic elements in general. This study takes a novel approach to the topic: through the investigation of defective object clitic paradigms in a number of northern Italian dialects and a comparison with the Raeto-Romance variety Surselvan, Brazilian Portuguese and contemporary French, this article proposes a reconstruction of the path that has led to the current situation, focusing on the emergence and loss of clitics, and the order by which this happens. The two processes also bear an interesting relation to one another: it seems that the order in which clitics are lost is the mirror image of the order in which they emerge. This is reminiscent of a parallel already observed by Jakobson (1941/1968) between language in its status nascendi (i.e. first language acquisition) and language in dissolution (i.e. aphasia).

Pronominal clitics differ from tonic pronouns in a number of ways (see Kayne 1975 among many others). Unlike tonic pronouns, clitics do not enjoy syntactic or phonological independence, and their existence is strictly tied to their host; they do not share the same distribution as full noun phrases or tonic pronouns; furthermore, they cannot be modified (e.g. Italian *Proprio la ho vista vs. Ho visto proprio lei 'I have definitely seen her') or coordinated (e.g. Italian *Lo e la ho visti vs. Ho visto lui e lei ' I have seen him and her'). On a pragmatic level, both pronominal forms can clearly be used when the referents are already present in the discourse as established topics, but only a clitic can be used to refer to an ACTIVE (in the sense of Chafe 1994: 53-55, i.e. a referent that is the focus of consciousness at a given moment) or expected referent. With respect to these properties the two types are in complementary distribution. As discussed in Section 3.1, a third category of pronouns has been identified, the so-called weak type (Cardinaletti \& Starke 1999), 
which have properties in common with both tonic and clitic pronouns but are crucially distinct from both.

Although typical of Romance, clitic pronouns are not present in all Romance languages: for example, partially or totally defective paradigms (within the accusative and dative series) feature in the Raeto-Romance ( $\mathrm{R}-\mathrm{R}$ henceforth) varieties spoken in Switzerland (see Haiman \& Benincà 1992) and in Brazilian Portuguese (see Galves 2000, Lucchesi \& Lobo 1996, among others). In the variety of Zernez (point 19 on the Atlante Italo-Svizzero), spoken in the Lower Engadin region of Switzerland, there is a set of accusative clitics (1a), but no clitic forms for dative (1b), partitive (1c) or locative (1d). ${ }^{2}(1 \mathrm{~b}-\mathrm{d})$ show how such deficiency is dealt with, the use of a tonic pronoun (preceded by a preposition) or a simple gap: ${ }^{3}$

(1) (a) ...ža tü il vowšt. Zernez

if you it.CL want

'... if you want it.'

(AIS VI:i, 1110)

(b) $\mathrm{Di}$ at el.

say to him.TON

‘Tell him!'

(AIS VIII:ii, 1659)

(c) Ce fesat vus kun el?

what do you with it.TON

'What would you do with it?'

(AIS VI:i, 1113), compare:

(c') Cosa ne fareste? Standard Italian

what of-it.CL would-do 
(d) Voleys ca yow $\varnothing$ geya. Zernez

want that I $\varnothing$ go

'Do you want me to go there?'

(AIS VIII:ii, $1638^{4}$ ), compare:

(d') Volete che ci vada io? Standard Italian

want that there.CL go I

Brazilian Portuguese (BP) has a defective clitic paradigm in that the third person forms seem to have disappeared completely. The accusative clitics $o, o s, a$ and $a s$ do not exist in the spoken language: they are only found in written and formal contexts and they are only acquired by children in school (Galves 2000: 147). In those contexts in which a third person clitic pronoun would be otherwise expected, speakers resort to either a nominative tonic pronoun (used with accusative function) for [+animate] referents as in (2a), or leave the object unexpressed (null object) with [-animate] referents as in (2b) (see Duarte 1989).

(2) (a) Amanhã, o meu filho viajará para São Paulo. Eu deixei ele $I^{*} \varnothing$ ir tomorrow the myson will-travelto São Paulo I let he.TON/ø go sozinho. BP

alone

'My son is leaving for São Paulo tomorrow. I am letting him go on his own.'

(b) Eu comprei o dicionário e emprestei $\varnothing / *$ ele ao João.

I bought the dictionary and lent $\varnothing /$ it.TON to-the João

'I bought the dictionary and lent it to João.' (Lucchesi \& Lobo 1996: 308) 
Furthermore, a third person dative object is preferably expressed by para followed by a tonic form: compare (3a) to its European Portuguese (EP) counterpart (3a'), which uses the clitic lhe. ${ }^{5}$

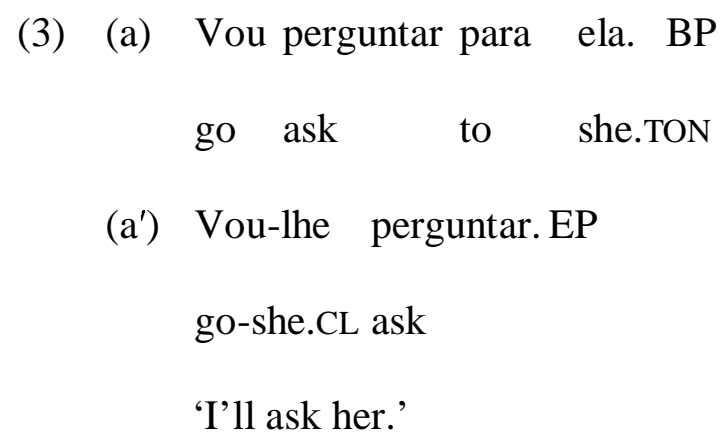

(from Azevedo 2005: 236)

A number of closely related so-called Italian dialects in the valley of Comelico, part of the Veneto region in North-eastern Italy, variously lack cells in the paradigm of accusative and dative atonic pronouns. ${ }^{6},{ }^{7}$ Differently from the R-R variety of Zernez, these dialects do have both a dative and an accusative series, but lack forms within both. Their defective paradigm had already been noted by Tagliavini (1926); however, the following is the first detailed account of these facts.

Although traditionally typological studies are carried out on a high number of genetically unrelated languages, conducting research on a small set of closely related varieties with the aim of making a typological contribution has its value and advantages, as eloquently and convincingly argued by Poletto (2012). Investigating linguistic systems that share the majority of their characteristics and minimally differ from one another in a limited and identifiable number of properties (in a similar fashion to two organisms that share most of their DNA and are differentiated by a few genes), offers the opportunity to zoom in on 
one variable and observe, without the interference of 'background noise', all its possible realisations, and, crucially, only those ones which are admitted by general principles of the faculty of language. Hence, although not in the same spirit as classic Typology, comparative micro-variation research of the following type affords the rare opportunity of observing patterns that can potentially result from general laws of language. ${ }^{8}$

This study has specific objectives. It firstly describes in detail the facts from Comelico on the basis of elicited as well as spontaneously produced data, and compares them to attested cases of clitic loss. Secondly, it relates the patterns with which this morphological defectiveness expresses itself to more general principles, the Referential Hierarchy in particular, that have been traditionally shown to affect the morpho-syntactic organisation of a variety of languages (e.g. number distinctions, differential case marking of transitive [ \pm animate] subjects, hierarchical verb agreement, as discussed in Comrie (1981)). The two aims are reflected in the way the paper is structured. The first part consists of a detailed description of the synchronic facts in the alpine varieties, which are then compared, in the second part, with a reconstruction of the process of emergence of clitic pronouns in (late) Latin, and with cases of varying degrees of clitic loss, Surselvan, Brazilian Portuguese and contemporary French. The two processes, emergence and loss, are discussed in Section 6 in relation to Jakobson's (1941/1968) LAWS OF IRREVERSIBLE SOLIDARITY and the Referentiality Hierarchy. Some concluding remarks and a few points left open for further research are provided in Section 7.

\section{THE COMELICO DIALECTS}

Comelico is the name given to the eastern Cadore, a Dolomitic area in the North-eastern 
Italian region of Veneto. The valley hosts closely related linguistic varieties that are different from those spoken in the surrounding areas: a variety of Tyrolean German to the west of this area, in the Sesto Valley; a German linguistic island, Sappada, separates it to the east from the Friulian varieties of Carnia, and Venetan dialects to the south. The dialects chosen for this investigation are those spoken in Padola, Candide, Danta, San Nicolò and Costalta. The phenomenon that is of interest here, empty cells in the object atonic paradigms, was first noticed in Padola and Candide by Tagliavini (1926: 68-69), who recorded the absence in the series of reflexes of Latin accusative nos 'we' and dative illi 'to him'. In subsequent notes (Tagliavini 1988: 69-70), he also commented on how the use of the accusative forms for the third person, $l a / l u$ 'her/him/it' and $i / l i$ 'them', was in fact extremely rare, and the corresponding tonic forms were preferred instead.

Padola and Candide are the geographical centre of the phenomenon, lacking the highest number of cells; San Nicolò, Danta and Costalta are at the periphery. The data presented throughout this article were collected using three methods of enquiry: a set of sentences and short dialogues served as basis for the oral investigation, which was conducted personally working with the informants; the observation of spontaneously produced data, both in the dialect and in regional Italian; and the consultation of written texts, modern and old. ${ }^{9} \mathrm{We}$ start with the accusative paradigm.

\subsection{Accusative pronouns}

All the varieties investigated have a complete series of accusative tonic pronouns. The atonic paradigm is deficient in the dialects of Padola (4) and Candide (5): both have forms for the first and second person singular and second plural, and both lack a form for the first 
person plural (4c), (5c). The use of a clitic for the third person, singular and plural, masculine and feminine, is not only restricted to [+animate] referents (4a, b), (5a, b), but also seems to be infelicitous in the plural $(4 d, e),(5 d, e)$, for which either a tonic form or a gap is preferred. ${ }^{10}$ It is interesting to note that in $(5 b, c)$, from Candide, a left-dislocated, [animate] direct object cannot be resumed by an atonic pronoun, while a [+animate] one (marginally) can (the same holds true for Padola). A summary for the forms in Padola and Candide is given in Table 1:

<Insert Table 1 about here>

The accusative clitic paradigm is complete in all the other dialects.

(4) (a) A: As-t vist Rosa? Padola

have-you.SCL seen Rosa

'Have you seen Rosa?'11

$\mathrm{B}: \mathrm{Si}, \varnothing$ ei vistu/?*ei vistu ila /l' ei vista ngeri. yes $\varnothing$ have seen /have seen her.TON /her.CL have seen.FEM yesterday 'Yes, I saw her yesterday.', 12

(b) A Maria piasi la pasta e $\varnothing / *$ la mangia ogni dì. to Maria pleases the pasta and $\varnothing$ /it.CL eats every day 'Maris likes pasta and she eats it every day.'

(c) A: Inú ve ceton? where you.CLfind 'Where can we find you?'

B: $\varnothing$ Ceted / Ceted noi in piäza. 
$\emptyset$ find / find us.TON in square

'You can find us in the square.'

(d) A: Sas-t algo d Maria e Bepo?

know-you.SCL something of Maria and Bepo

'Do you have any news of Maria and Bepo?'

B: Si, $\varnothing$ ei vist / ?li ei visti /?*ei vist lueri ngeri

yes $\varnothing$ have seen / them.CL have seen/ have seen them.TON yesterday

e sta benon.

and are great

'Yes, I saw them yesterday and they are doing well.'

(e) A Maria piasi i fonghi e $\varnothing / *$ li mangia sempre d'istiadi. to Mariaplease the mushrooms and $\varnothing /$ them.CL eats always of summer 'Maria likes mushrooms and she always eats them in the summer.'

Example (4a) above is interesting, as it shows that when a third person form is used for a feminine referent, the past participle shows agreement, while with a gap no such agreement is triggered, indicating that the form is not just phonetically unrealised but syntactically inactive, hence totally absent.

(5) (a) A: As-t vist Rosa? Candide

have-you.SCL seen Rosa

'Have you seen Rosa?'

B: Si, $\varnothing$ eiu vist / ?*eiu vist vela / 1' eiu vista ngeri. 
yes $\varnothing$ have seen / have seen her.TON / her.CL have seen.FEM yesterday 'Yes, I saw her yesterday.'

(b) A: Che à decisu da fèi col trator e la ceda? what have decided to do with-the tractor and the house 'What have they decided to do with the tractor and the house?'

$\mathrm{B}$ : Al trator $\varnothing / * 1$ ' à vandù e la ceda $\varnothing / * 1$ ' à fitó. the tractor $\varnothing /$ it.CL have sold and the house $\varnothing /$ it.CL have rented 'As for the tractor, they have sold it, and as for the house, they have let it.'

(c) A: Che fa i canai d' istiadi? what do the chidren of summer 'What are the children doing in the summer?'

B: Luca (?lu) mandon z i noni, Maria (?la) mandon z Luca him.CLsend to the grandparents Maria her.CL send to colonia.

summer-camp

'As for Luca, we are sending him to his grandparents, and as for Maria, we are sending her to a summer camp.'

(d) $\varnothing$ Sentidi? /Sentidi néi?

$\emptyset$ hear /hear us.TON

'Can you hear us?'

(e) A: E Maria e Bepu? and Maria and Bepu? 'And what about Maria and Bepu?' 
B: $\varnothing$ Eiu ciatad /?*Eiu ciatad leri / in piäza e sta benon. $\varnothing$ have met /have met them.TON / in square and are great 'I have met them in the square and they are doing great.'

(f) A Maria piasi i fonghi e $\varnothing$ coi dutu l'istiadi. to Maria please the mushroom and $\varnothing$ picks all the summer 'Maria likes mushrooms and she picks (them) all summer.'

A few points are worth mentioning here. In those cases in which the referent is animate and both a gap and a tonic pronoun can be used (i.e. first person plural and, very marginally, third person), the two forms appear to be in free variation. Furthermore, both a gap and tonic pronouns can be used for an active/expected referent: thus in (4a) and (5a), allowing for the marked marginality of the tonic pronoun, neither a gap nor a tonic pronoun introduce a change of topic or express a contrast. This suggests that the tonic pronouns are being re-analysed as weak (in the sense of Cardinaletti \& Starke 1999); this possibility is investigated and discussed in Section 3.1. It also seems that the animacy feature plays an important role in the realization of a referent as an atonic form. Crucially, even in those dialects (e.g. the variety spoken in Danta) that have a complete atonic paradigm, a gap is possible for the third person with [-animate] referents, both in the singular and plural. Some examples for the plural are shown in (6): when the referent of the pronoun is [animate] as in (6b), a gap is possible, unlike when it is [+animate], as in (6a).
(6) (a) A: Sas-to
algo
d Maria
e Giuseppe?
Danta
know-you.SCL something of Maria and Giuseppe 
'Do you have any news of Maria and Giuseppe?'

B: Si, li $\quad / ?^{*} \varnothing$ vedo doman e $\quad$ i sta bén. yesthem.CL/ $\varnothing$ see tomorrow and they are well 'Yes, I am seeing them tomorrow and they are doing well.'

(b) A Maria pias i fonghe e li /ø mangia senpro d'istiade. to Maria please the mushrooms and them.CL / $\varnothing$ eats always of summer 'Maria likes mushrooms and she always eats them in the summer.'

The next set of spontaneously produced sentences in the varieties of Padola (7) and Candide (8) exemplify the strategies that the grammatical system offers to circumvent the lack of an atonic form: the use of the tonic pronoun (7a) or a gap (7b) for the first person plural both in the dialect and in regional Italian (7c), a gap for third person [-animate] in the dialect (7b) and in regional Italian $(7 d)$, and $(8 a, b)$ in the dialect of Candide.

(7) (a) (Recalling old traditions in Padola: at the end of a procession, young men would pluck up courage and go and ask the hand of their sweetheart; her father, trying to get to know the young man, would ask him some questions):

... À scumanzeu a dumandà algu e anchi a dì cali ch pudé esi li bravuri e anchi i difeti d'so fie, disendu 'Leve su bunore, va a mese, iute semper noi zi nosi lavori, sa fei algo cule gusele" ...'

'He started to ask something and to say which could be the good and bad sides of his daughter, saying "She gets up early, she goes to Mass, she always helps us.TON in our activities, she can sew" ...' 
(b) (Recalling how the Regole, the administrative local powers, used to allocate wood to the people in Padola):

... Canc té fore l'avisu che gné dadi fore i legni, la denti s'ingrumà danti la cese dla Regule, parché tanti oti ne n'ere asei par duci e alore vardà da esi i primi par pudé ciapà $\emptyset[. .$.$] Can ch'ruà zal pian, li femni \emptyset$ gné incontre par iuté $\emptyset$ a tire $\emptyset$ a cese. [...] S disé ch'i i legni s'aude cuater oti: n'ote a fei ø, n'ote a mnà $\emptyset$, n'ote a pestà $\emptyset$ su e l'ultme a bursé $\emptyset$... ${ }^{13}$

'When the notice that the wood (lit. 'the woods') would be distributed was put out, people would gather in front of the town hall, because very often there wasn't enough for everybody and so (one had) to try to be the first in order to be able to receive it. $\varnothing[\ldots]$ When they reached the valley, the women would come to meet us to help us. $\varnothing$ to drag it. $\varnothing$ home [...] People used to say that wood burns (i.e. it produces heat) four times: one when cutting it. $\varnothing$, one when transporting it. $\varnothing$, one when breaking it. $\varnothing$ up and the last one when burning it. $\varnothing$...'

(c) (A lady from Padola, recalling Sundays with her late husband, regional Italian: ... eh, quando Giovanni era vivo lui lavorava sempre. Partiva la mattina presto e tornava sempre tardi tanto che io dicevo 'È sposato al lavoro' ... ma la domenica era dedicata alla famiglia. Diceva sempre 'Oggi non si lavora’, e lui ø portava sempre al ristorante, e le figlie erano tutte orgogliose, capirai ...

'Ah, when Giovanni was alive he worked all the time. He used to leave early in the morning and come back late, so that I used to say "He's married to his job" ... but Sundays were devoted to the family. He used to say: "No work today" and he used to always take us. $\varnothing$ to the restaurant and our daughters were all proud, you 
can understand ...'

(d) (A boy from Padola, telling off a friend who, playing with it, has just broken the aerial on his car):

Vé mo, t' $\emptyset$ as rotu!

'See, you have broken (it)!

(8) (a) (From a conversation between two librarians, Candide):

Da pech tenpu à publicò n libar cu li satiri d carnaval di ani '40 e '50 e '60 de San Nuclò, chestu è neu e l'Istituo n $\emptyset$ à ncamò, ei da purtà $\emptyset$ fora io sta stmana ch ion.

'Recently they have published a book with the Carnival speeches from the Forties, Fifties and Sixties from San Nicolò, this is new and the Institute does not have it. $\varnothing$ yet, I have to bring it. $\varnothing$ out next week.'

(b) (From the recounting of a pilgrimage to Luggau):

Cunton da pudé ncamò dì ze sta maniera. È pì d cuaranta chilometri, ma val la pena fèi $\emptyset$.

'We're counting on going again like this. It's more than forty kilometres, but it is worth walking them. $\varnothing \backslash$ doing it. $\varnothing . '$

Table 2 shows the various forms used as accusative atonic pronouns across the five varieties.

<Insert Table 2 about here>

Let us now turn to the dative paradigm. 


\subsection{Dative pronouns}

The dative atonic paradigm is defective in three dialects, Padola (9), Candide (10) and San Nicolò (11). They all lack third person datives (both feminine and masculine, singular and plural), as shown in (9a), (10a), (11a); in addition, Padola and Candide do not have an atonic form for the first person plural, (9b), (10b):

(9) (a) $\mathrm{N}$ ved mai Maria, ma øèi telefoneu lèi telefoneu a ila NEG see never Maria but $\varnothing$ have phoned /have phoned to her.TON ngeri. Padola

yesterday

'I never see Maria, but I phoned her yesterday.'

(b) $\varnothing$ Das-t $\quad$ Das-t a nuietar zinc panins?

$\varnothing$ give-you.SCL /give-you.SCL to us.TON five bread-rolls

'Could you give us five bread rolls?'

(10) (a) A: As-t dò la culazion ai canai? Candide have-you.SCL given the snack to-the children 'Have you given the snack to the children?'

$\mathrm{B}: \mathrm{Si}, \varnothing$ ei dò lei dò a lueri ali tre. yes $\varnothing$ have given /have given to them.TON at-the three 'Yes, I have given it to them at three o'clock.'

(b) $\varnothing$ Dadedi i panins? /Dadedi i panins a nuietar? $\emptyset$ give the bread-rolls /give the bread-rolls to us.TON 'Could you give us the bread rolls?' 
(11) (a) Par fèi la multa a Mario, la polizia øè corosta davòi /è corosta for make the fine to Mario the police $\varnothing$ is run after /is run davòi a lì par $\mathrm{n}$ chilometro. San Nicolò after to him.TON for one kilometre 'In order to give Mario a fine, the police chased him for one kilometre.' (b) $\mathrm{Ne}$ das nesche panins? /Das a nèi nesche panins? to-us.CL give some bread-rolls /give to us.TON some bread-rolls 'Could you give us some bread rolls?'

The following spontaneously produced sentences (12 from Padola, 13 from Candide) show the use of a gap (12) or a pronoun + tonic form (13) when an atonic third person form does not exist:

(12) (Recalling old traditions in Padola, as in (8) above: at the end of a procession, young men would pluck up courage and go and ask the hand of their sweetheart, and the young man would be paralysed with fear):

... E intantu che la mari fnì i servisi al pari ciapà z man la situazion. Magari ø dumandà 'che as-t fatu incui' e davardé al discorsu. ... 'And while the mother was finishing the cleaning, the father would take the situation in hand, perhaps asking (to) him.ø "What have you been up to today?" and so he would get the conversation going ...'

(13) (Recalling the role of the school teacher a few years back): ... Era ancamò al rispetu par la figura dal maestar ch gné vista com na persona 
nportanti par al peis e a lì se ubdì senza tant lumantassi ... Candide

'There was still respect for the role of the teacher, who was seen as an important person for the village, and one would obey (to) him.TON without much complaining

In the dialect of Danta, which has a complete set of dative clitics, those for the third and first person plural are in free variation with the tonic pronouns, and for the third person, in addition to these, a gap is also an option:

(14) (a) Pr fèi la multa a Mario, la puliziai / é corosta davoi for make the fine to Mario the police to-him.CL $/ \varnothing$ is run after lé corosta davoi a lì pr $\mathrm{n}$ chilometro. Danta /is run after to him.TON for one kilometre 'In order to give Mario a fine, the police chased him for one kilometre.'

(b) A: ‘̀ telefonò ai canaie Nani? has phoned to-the children Nani 'Has Nani phoned the children?'

$\mathrm{B}: \mathrm{Si}, \mathrm{i} \quad /$ à telefonò /à telefonò a luere incuei. yes to-them.CL / $\varnothing$ has phoned /has phoned to-them.TON today 'Yes, he phoned them today.'

(c) $\mathrm{N}$ das-to di panins? /Das-to di panins a nèi? to-usCL give-you.SCL of bread rolls/give-you.SCL of bread-rolls to us.TON 'Could you give us some bread rolls?' 
A similar situation is found in Costalta: in spite of a complete dative paradigm, third person and first person plural can be realized by a tonic form (again, in free variation with the atonic pronoun), but not, crucially, by a null form:

(a) $\mathrm{N} \quad / * \varnothing$ à mandói libre /À mandói libre a nöi. Costalta to-us.CL / $\varnothing$ have sent the books /have sent the books to us.TON 'They have sent us the books'

(b) $\mathrm{N}$ i $\quad / \mathrm{N} * \varnothing$ antaressa nente! /A öla $\mathrm{n}$ antaressa nente! NEG to-her.CL /NEG $\varnothing$ interests nothing/to her.TON NEG interests nothing 'She is not interested at all!'

Table 3 offers a summary of the forms used as atonic pronouns in the dative across the five varieties.

<Insert Table 3 about here>

As a final summary, Tables 4 and 5 present an overview of the existence (indicated with a tick ' $\checkmark$ ') or non-existence (indicated with a cross ' $x$ ' and shading) of accusative and dative atonic pronouns across the five varieties. In those cases in which the clitic form is in free variation with the tonic form or a gap, the tick is in between parentheses.

<Insert Table 4 about here>

<Insert Table 5 about here>

\section{DISCUSSION OF THE COMELICO FACTS}


The synchronic defective paradigms of the atonic pronouns in the Comelico dialects can be the result of two logical diachronic possibilities. The first, arrested development, accounts for the missing forms by assuming that they never developed. The second, decay, attributes the defectiveness to a process of loss: the paradigm was complete and then at some stage some forms disappeared.

By the very nature of defectiveness, any attempt to reconstruct its diachronic path faces significant challenges. However, one can bring forward the evidence that is available and on the basis of that make informed speculations and reach a plausible reconstruction. This is what this section sets out to do.

In support of the arrested development hypothesis there is the case of incomplete subject clitic paradigms in the Northern Italian Dialects (NIDs). Vanelli (1987) places the emergence of subject clitics in the NIDs between the $15^{\text {th }}$ and $16^{\text {th }}$ centuries, and interprets it as the result of a weakening process of the nominative tonic pronouns. Pescarini (2009) observes how in some Medieval Veronese texts there is clear evidence that this weakening process does not target all persons equally. While some forms clearly develop into clitics, others do not, possibly remaining at an intermediate stage and eventually being lost: this would explain the incomplete series of subject clitics found in some NIDs. Pescarini's observations are perforce inconclusive, since the relevant data are not forthcoming and clearly limited; nevertheless his remarks cast some doubts on the assumption that all NIDs had, at some stage, a complete paradigm of subject clitics which was subsequently eroded in some cases.

The decay hypothesis is supported by attested and well-known examples of loss of atonic forms in Surselvan and Brazilian Portuguese: in both cases there is written evidence 
of a stage in which atonic pronouns existed alongside tonic pronouns and displayed clear clitic behaviour. Furthermore, from the very restricted and admittedly not totally reliable diachronic evidence that exists for the Comelico dialects, and from the evidence in the peripheral areas, it seems that there is reason to believe that the current defective paradigms are the result of a process of decay. ${ }^{14},{ }^{15}$ This is the hypothesis that is pursued and investigated here.

As for the reason behind this decay, given the close proximity with a German-speaking area, the neighbouring Sesto Valley, it could be argued that the synchronic situation in Comelico is the result of language contact/proximity with German varieties. This does not seem immediately plausible for a number of reasons. First, a physical one: the Comelico Valley is separated from the German-speaking area by a mountain pass (Passo Monte Croce di Comelico, Kreuzbergpass), which incidentally also separates two provinces, as well as two regions, Belluno (Veneto) from Bolzano (Trentino Alto Adige), and at the time of the First World War it also marked a national boundary, between Italy and the AustroHungarian Empire. Secondly, there is a clear cultural separation between the two valleys: as noted by Vàrvaro (1984: 143-144), the signs of a close-knit community are visible in their linguistic code even before they affect dress code and behaviour. While the Sesto Valley is clearly 'German', Comelico is very much 'Italian' (see also Tagliavini 1926). It is also hard to imagine any language contact symptoms revealing themselves in the loss of something of a grammatical nature, such as atonic pronouns, when the lexis, which is the area typically affected first in the contact between two stable linguistic communities, displays no signs of a significance presence of German lexical units. Finally, a recent article by Kaiser \& Hack (forthcoming) makes a convincing case against German language contact 
being the reason behind the loss of object clitics in some R-R varieties: they argue, instead, that the process was naturally happening in these varieties and the contact with German provided the supportive environment needed for the maintenance and the further development of the already existing trends.

If, however, one still finds these arguments unconvincing, the simple fact that the cells within these paradigms have not been affected equally by the process is, in itself, of linguistic and typological relevance and appeal. It seems therefore interesting to investigate the nature of the hierarchy along which such a change is operating and try and place it within the wider context of principles that govern language change. Accordingly, we sketch the possible development, to the extent that it can be plausibly reconstructed, of these defective paradigms.

\subsection{The status of the Comelico pronouns}

The discussion so far has intentionally remained unspecific about the exact morphosyntactic status of the pronominal forms in Comelico. It has been recognised (and generally accepted) that the label 'atonic' subsumes (at least) two types of forms, weak and clitic, as discussed in Cardinaletti \& Starke (1999). While the former are assumed to be maximal (i.e. phrasal) categories, alongside tonic forms, the latter are best analysed as heads. Both weak and clitic pronouns are considered syntactically and pragmatically deficient/dependent. This is reflected in their behaviour: a summary of the properties of all three categories is provided in Table 6.

<Insert Table 6 about here>

In an attempt to establish the exact nature of both the atonic and tonic pronouns, we focus 
on doubling, left-dislocation, clitic climbing and pragmatics in the dialect of Padola.

Only clitic pronouns can 'double' a strong or weak pronoun in the so-called doubling construction (Cardinaletti and Starke, 1999:169), hence while (16a) works, (16b), in which the doubling of the strong pronoun a loro is done by the weak loro, does not:
(a) Gliel'
ho dato loro
/ a loro.
to-them.it.CL have given them.WEAK / to them.TON
(b) *L' ho dato loro a loro.
it.CL have given them.WEAK to them.TON
'I gave it to them.'

Doubling constructions do not feature in the Comelico varieties, even in those cases in which most Northern (and Southern) varieties require the presence of a clitic. Compare (17a) from Triestino, one of the NIDs, and $\left(17 b^{\prime}\right)$ from Padola: even if in Padola the atonic pronoun exists (17b), it cannot co-occur with the tonic pronoun.
(17)
(a) A ti $\quad *$ (te) piasi le luganighe. Triestino
to you.TON to-you.CL please the sausages
'You like sausages.'
(b) Te pias li luganghi. Padola
to-you.CL please the sausages
(b') *Ati te pias li luganghi.
to you.TON to-you.CL please the sausages 
'You like sausages.'

The ungrammaticality of $\left(17 b^{\prime}\right)$ could be due to the fact that te is not a clitic but a weak pronoun; however, it could also be due to the same constraint that prevents doubling of a strong pronoun in Italian (*A te ti piacciono le salsicce 'You like sausages'). This does not, crucially, depend on the nature of the atonic pronoun (which is clearly a clitic in Italian), but on the availability of doubling constructions in general. Since we cannot settle the matter here, we take this particular piece of evidence as inconclusive and consider further properties.

Only clitic pronouns can resume a dislocated strong pronoun, witness the ungrammaticality of (18b):

(a) A loro, gli regaliamo un album. Standard Italian

to them.TON to-them.CL give

a photo-album

'As for them, we can give them a photo album as a present.'

(b) *A loro, regaliamo loro un album.

to them.TON give to-them.WEAK a photo-album

'As for them, we can give them a photo album as a present.'

In Padola a left-dislocated accusative tonic pronoun can be resumed by an atonic form; this is only testable for [+animate] referents, since inanimate referents cannot be expressed by tonic forms (see Cardinaletti \& Starke 1999: 145): 
(19) (a) Te, te ciama alolo. Padola

you.TON you.CLcall now

'As for you, they will call you now.'

(b) A: Sas-t algo d Maria e Bepo?

know-you.SCL something of Maria and Bepo

'Do you have any news of Maria and Bepo?'

B: Ila, n la ved mai, e lì, l' ei vistu ngeri.

she.TON NEG her.CL see never and he.TONhim.CLhave seen yesterday

'As for her, I never see her, and as for him, I saw him yesterday.'

Only clitic pronouns can 'climb' to the front of the verbal (quasi)modal-infinitive complex:

(20) (a) Voglio vederlo / Lo voglio vedere. Standard Italian

want to-see-him.CL him.CLwant to-see

'I want to see him.'

(b) Voglio vedere lui / $*$ Lui voglio vedere. (with neutral intonation)

want to-see him.TON him.TONwant to-see

'I want to see him.'

'Climbing' constructions are possible in Padola:

(21) (a) Maria te vuä vede alolo. 
Maria you.CL want to-see now

'Maria wants to see you now.'

(b) Giuani ve vuä vede alolo.

Giuani you.CLwant to-see now

'Giuani wants to see you now.'

Finally, atonic pronouns cannot be used to introduce a pragmatically salient (e.g. contrastively focused and indicated in bold in the examples in (22)) or new referent:

(22) (a) *Lueri te scolta, no lì.

they.TON you.CLlisten-to not him.TON

(b) Lueri scolta te, no lì.

they.TON listen-to you.TON nothim.TON

'They are listening to you, not him.'

Summarising, these atonic elements can co-occur syntactically with left dislocated tonic pronouns and can 'climb' a verb complex; pragmatically, too, they can only refer to active or non-prominent referents, and cannot be contrastive. With respect to these properties, they display clitic behaviour. The impossibility of doubling constructions, even for a person for which the atonic pronoun exists, may be due to unrelated reasons which we do not investigate here.

Tonic pronouns display all properties listed in Table 6 that are clearly associated with tonic forms. In addition, we have seen that a seemingly tonic form can be used 
anaphorically in contexts that would require a clitic pronoun in modern Italian. Similar cases have been noted in Old Italian (see Egerland \& Cardinaletti 2010: 414), and have been taken to be instances of weak rather than tonic pronouns: thus tonic and weak appear identical in form but have different properties.

It can be concluded that there are possibly three types of pronominal forms in the Comelico varieties, clitic, tonic and weak; although tonic and weak pronouns are morphologically identical, they display, as we have seen for Padola, distinct behaviour. A summary of the weak forms in the accusative and dative for all the varieties is offered in Table 7.

<Insert Table 7 about here>

The existence of atonic pronouns with clear clitic behaviour is significant, as it indicates that, at least in the varieties of Padola and Candide, the clitic series has, indeed, developed. This in turns supports the hypothesis that the defective paradigms really are the result of a process of decay; no such conclusion can be drawn for first person plural, which is discussed as a separate case in the next section .

\subsection{Identifying hierarchies}

The defective paradigms described in the previous section are not all that is interesting about the Comelico varieties: also of interest are the strategies made available by the linguistic system when dealing with a missing cell, as well as what is optionally available when a linguistic item for a given cell does exist, as all of these reveal the morpho-syntactic status of the pronouns. The alternatives used to deal with the lack of a clitic pronoun are mainly two, a gap or the use of a the tonic/weak form instead: the complementary 
distribution in terms of both pragmatic and syntactic properties between morphologically tonic and atonic forms that is typical of other Romance varieties does not seem to hold in Comelico, suggesting that seemingly tonic forms, indeed, subsume both tonic and weak pronouns .

The distribution of the tonic and clitic forms and of the gaps is also interesting in those cases in which the clitic form exists but other alternatives are available. Padola and Candide which, as we have seen, have the highest degree of defectiveness, prefer a gap to the use of the first person singular clitics (the use of the tonic form is felt as unnatural). In San Nicolò, Danta and Costalta, in which a clitic form for the first person plural exists, it is found in free variation with the tonic/weak form. In Danta we find that for the third person all three solutions are used: clitic, tonic/weak and a gap.

In the light of the conclusions reached in Section 3.1, and placing these facts against the wider Romance background, it seems that the Comelico dialects are undergoing a process of loss that has reached different stages in the five varieties. The existence of clitic pronouns, the blurred boundaries in the division of labour between tonic and clitic forms, as well as the possibility of zero realization, all point in the direction of a situation of loss: loss of specialization, in that the tonic forms are weakening, and loss of forms, as the clitic pronouns are gradually substituted by the original tonic pronouns, now weak, first, and eventually by gaps. Tables 4 and 5 offer an overview of this pattern of loss and identify the forms that are affected first: the more numerous gaps in the dative paradigm suggest that dative has been affected before accusative (along similar lines to what observed by Benincà $\&$ Poletto 2005) and some grammatical persons before others. The data clearly single out first person plural (which is completely absent in both Padola and Candide and optionally 
omitted in other dialects), and third person singular and plural. Maintaining that Padola and Candide indeed represent the epicentre of the phenomenon, their 'optional' gap for the first person singular in the dative may point to this as the next target of the process.

The consistent absence of the clitic forms for the first person plural suggests that this is the form that was targeted first by the process of decay: this is, from a cross-linguistic perspective, an unusual fact (see Farrell 1990: 329ff), as a null object pronoun has a DEFAULT interpretation of third person, which suggests instead that in a process of loss the third person is the first one to disappear. It is possible that the Comelico facts do indeed fall within the more usual pattern and that the behaviour of first person plural is the result of a process unrelated to the one affecting the other forms: it could, for example, have never developed (either accidentally, or as a result of possible homophony with negation, as the Old Italian first person plural clitic form was no); or it could have been lost at an earlier stage for different reasons (possibly being homophonous with either of the two nonargumental partitive or locative clitics, absent in all dialects: as observed by Benincà \& Poletto (2005) non-argumental clitics are lost before argumental ones. This explanation, however, would not account for the fact that a clitic form does exist for the second person plural, which is subject to very similar syncretism, having developed from a Latin locative). ${ }^{16}$ As pointed out by Benincà \& Poletto (2005a) who break pronouns down into basic features such as $[ \pm$ hearer $],[ \pm$ speaker $], \pm$ there $]$ and $[ \pm$ here $]$, first and second person plural pronouns can express a 'heavy load'. First person plural, in particular, could include any of the following readings (Benincà \& Poletto 2005a: 280):

(23) (a) the speaker and only one hearer; 
(b) the speaker and more than one hearer;

(c) the speaker, one hearer and somebody else who is not present;

(d) the speaker, one hearer and several persons who are not present;

(e) the speaker, more than one hearer and somebody else who is not present;

(f) the speaker, more than one hearer and several persons who are not present.

Furthermore, many Italo-Romance dialects have two forms for the first person plural tonic pronoun, the reflexes of Latin nos 'we' and nos alter lit. 'we others'. The two can survive alongside each other and have specialised meanings based on the inclusive/exclusive distinction. Padola and Candide have both forms: with respect to the readings in (23), noi and nèi 'we' include the speaker, the hearer and various people who are not present; nuietar and nuiétar 'we others' exclude the hearer. For the second person plural, on the other hand, there is no such choice, and only the reflexes of vos alter exist, which has come to mean general 'you'. Interestingly, all the other dialects, which have an atonic form for the first person plural, only have one form for both first and second person plural. It was suggested in Paoli (2009: 79) that an atonic form, defective in semantic, phonological and syntactic terms, may not have been able to 'cope' with the information overload associated with the tonic form in general exemplified in (23), and with the inclusive/exclusive feature specific to Padola and Candide. The result of this inadequacy would have been lack of development (or, at the very least, very early loss). Following this line of reasoning, second person plural would be 'immune' from such inadequacy because of the lack of lexicalisation of the inclusive/exclusive distinction by the pronominal forms. Although these are tentative explanations at this stage, it seems plausible to consider the 
case of first person plural as separate: some justification for this choice is also derived from Surselvan and Brazilian Portuguese data in Section 5.

If the first person plural is taken out of the equation, the picture that emerges is not only more familiar, but also meaningful: the third person is affected first by the process of decay, and it is [-animate] referents that are more readily expressed by a null form (see Padola, Candide and Danta). Providing a rough approximation of the order in which these forms are disappearing, we obtain the Person hierarchy in (24):

(24) $3^{\text {rd }} \mathrm{sg}[-$ anim $>+$ anim $]>3^{\text {rd }} \mathrm{pl}[-$ anim $>+$ anim $]>1^{\text {st }}, 2^{\text {nd }} \mathrm{sg}>2^{\text {nd }} \mathrm{pl}$

There is also a process of re-analysis of the pronominal forms, as the original tonic pronouns weaken and, together with gaps, they substitute the original clitics. The stages of such a process are shown in (25): here a possible final stage has been added, witnessed in Surselvan.

(25) tonic and clitic forms in clear-cut domains > tonic and clitic forms in free variation (tonic $>$ weak?) > gap alongside clitic and/or tonic (weak?) form > gap preferred > re-introduction of tonic forms?

The discussion of these facts is resumed in Section 5. We now turn to the emergence of object clitic forms in the path from Latin towards Romance.

\section{From LAtin to Romance}


The purpose of this section is to try and reconstruct the developmental path followed by the atonic pronouns in (proto-)Romance. ${ }^{17}$ This will prove necessarily an exercise of educated guessing, as there exists no uncontroversial evidence to attest early signs of the process, or to show whether it had targeted some forms before others: written sources do not readily display any early symptoms that a change was under way except in those cases in which metre was clearly affected. ${ }^{18}$ Furthermore, the relevant evidence is not easily available, as Latin was an object-drop as well as a subject-drop language: the presence of an overtly expressed object was required predominantly in those cases in which pragmatic salience made it necessary, and only a subset of these were instances in which this was done through the use of a pronoun. It is not until $800 \mathrm{AD}$, in the early medieval parody of the Lex Salica, that we find the first attestation of a written third person clitic pronoun in the modern form (Wanner 1987: 68).

It is generally accepted that Latin did not have any pronominal clitics as we know them today. Pronouns in a traditional sense only existed in Latin for the first and second persons and for the third person reflexive (see Wanner 1987: 67), the third person otherwise availing itself of demonstratives of different types. ${ }^{19}$ Although the claim has not been systematically made and independently justified, there is evidence for two prosodically distinct versions of the same forms in Latin: often the same Latin pronominal form developed into two distinct elements in Romance. Salvi (2001: 286 ff.), referring to Schwan \& Behrens (1913: 13), cites the two Old French forms, tonic and atonic respectively, mei/moi and me: these, a clear development from Latin ME, could only be the result of a respectively stressed and unstressed use of the form, yielding the expected development of tonic [e] into the diphthong ei/oi and of atonic [e] into a [ə]. 
Pragmatically, too, the Latin forms could function contrastively as well as simply refer to an expected/active referent, clearly subsuming the roles that would be taken on in Romance by tonic and clitic pronouns respectively. ${ }^{20}$ In (26a) the pronoun tibi 'to you' is contrasted with the author himself, Cicero, who is referred to with the emphatic pronoun mihimet; in (26b) no such contrast exists, and eum 'him' is simply used to refer back to its active antecedent Demetrius: the very presence of the pronoun may indicate that the form is behaving, (at least) pragmatically, in an atonic way.

(26) (a) Tibi autem idem consili do quod mihimet ipsi (Cicero, Epistulae ad familiares, IX.2.2, in Salvi, 2001: 286)

'I give you the same advice I give to myself'

(b) Demetrius venit ad me [...] Tu eum videlicet non potuisti videre (Cicero, Epistulae ad familiares, XVI.17.2, in Salvi, 2001: 286)

'Demetrius came to visit me [...] you were evidently not able to see him'.

On the basis of these facts, it therefore makes sense to assume that the Latin pronominal forms already displayed part of those properties that were going to characterise Romance clitics. As Wanner points out, the 'real' pronouns (i.e. first and second and third reflexive) had the potential to behave in a clitic-like manner from the earliest days:

The I, II and III refl[exive] forms lead without any break into the Romance clitic expressions; any one of them is able to represent a special or simple clitic or nonclitic form in early Late Latin. But the third person non-reflexives (ill-, ips-) are 
preserved in the texts in their full, bisyllabic form for a long time (at least in writing), so that they appear only in the eighth century in consciously 'vulgare' texts with typical apheresis'. (Wanner 1987: 87-88)

This property only became available to third person pronouns much later in the evolution, as they had 'to drop from their strong status to simple reference function' first (Wanner 1987: 76).

There therefore seems to be a strong enough case to claim that the (proto-)clitic use of first and second person preceded the same development of the third person. This offers a first approximation of a hierarchy of the emergence of clitic forms, shown in (27), where '>' is to be understood as diachronic precedence:

(27) $1^{\text {st }}$ and $2^{\text {nd }}>3^{\text {rd }}$

(27) is also an implicational hierarchy: where the order in (27) holds, it is expected that the presence of a clitic form for the third person will imply the existence of clitic forms for first and second, too.

We can also draw a parallel hierarchy, concerned with the relationship between form and function:

(28) tonic forms used both in a tonic and atonic manner (possibly becoming weak?) > weak/clitic usage restricted to specific positions > gradual phonological and morphological erosion of the forms in their clitic usage > distinct sets of clitic forms are developed with correspondingly distinct functions from tonic forms. 
(27) and (28) represent the path followed by the development of clitic pronouns from Latin to Romance. The next section turns to the discussion of two attested cases of clitic loss, Surselvan and Brazilian Portuguese, and makes some reference to a change in progress in contemporary French.

\section{THREE CASES OF CLITIC LOSS}

\subsection{Surselvan}

Of the R-R varieties, Surselvan is the only one that completely lacks a pronominal object clitic series, and uses the tonic pronouns instead. This is the result of a process of loss that has taken place over the last several hundred years. Clitics are still witnessed in the $16^{\text {th }}$ century: the text Vita de Soing Giosaphat. Convertius de Soing Barlaam 'Life of Saint Josaphat converted by Saint Barlaam' and the 1591 diary Cudisch dilg viadi da Jerusalem 'Book of the journey to Jerusalem' (Decurtins 1880-1883: 255-296; 151-196, respectively) offer an insight into the process of loss and the path it followed. Barlaam and Josaphat is a legend of Indian origin, but it was an Italian version that served as the model for this translation (Ascoli 1880-1883: 417). This particular manuscript edited by Decurtins dates from the $17^{\text {th }}$ century, and has some $18^{\text {th }}$ century amendments (Decurtins $1880-1883$ : 255). The Diary was written by Jacob Bundi during his pilgrimage to the Holy Land, although the version available is not the original but a copy that dates from the beginning of the $18^{\text {th }}$ century. The language of both texts is identified as Surselvan. ${ }^{21}$

Here we focus on the Barlaam and Josaphat text, since it contains the complete array of the pronouns. The Diary is written with the narrator as first person plural, hence the 
abundance of these forms is a helpful term of comparison to shed some light on the case of the first person plural in Comelico.

In the text the only two forms that are morphologically distinct (in the orthography) in what appears to be their tonic and atonic usage are first and second person singular accusative. No atonic forms are found for third person plural in either accusative or dative. An inventory is given in Table 8:

<Insert Table 8 about here>

In addition to these pronominal forms, for the third person demonstratives are also used, mainly for [-animate] referents: quel 'that one (masc)' and quel(l)a 'that one (fem)'. Given that the morphological differences between the tonic and atonic types are minimal, and that orthography is itself unreliable as shown by the frequent inconsistencies in spelling, the only reliable way to identify atonic pronouns is from their syntactic and pragmatic behaviour. The following are the properties that have been taken into consideration:

\section{(29) (a) Atonic/Clitic:}

- immediately precede finite verbs;

- can undergo clitic-climbing;

- do not express a contrast;

- $\quad$ refer to an active referent;

(b) Tonic:

- $\quad$ are placed in post-verbal object position (or after a preposition);

- can be coordinated with an NP; 
- express a contrast;

- introduce a new referent.

Alongside the two types of pronouns the text also shows an abundance of gaps, and the breakdown of the variation for each person both in the accusative and dative is offered in Tables 9 and 10 (a ' $\checkmark$ ' for any given cell means that there are attestations of that form used for that cell; a ' $x$ ' means that that particular form is not attested for that given cell).

<Insert Table 9 about here>

<Insert Table 10 about here>

Finally, Table 11 summarises the findings in both accusative and dative organised according to person. ${ }^{22}$

<Insert Table 11 about here>

The interchangeability of usage for clitic and tonic pronouns and gaps is of interest: it reveals that the original tonic forms are weakening, and the original clitic forms are being substituted by gaps. Representative of this are the examples in (30): (30a) shows a case of coordination reduction, and in the same sentence all three forms are found, a clitic, a gap, and a tonic pronoun, all referring to the same individual; (30b) and (30c) show a clitic-like use of a tonic pronoun (i.e. pragmatically non salient, as determined by the context), indicating that the seemingly tonic form is actually weak; finally, (30d) shows how $m i$ can occupy a position to the left of the verbal (quasi)modal-infinitive complex, a property typical of clitics. 
(30) (a) ... Ti mi has giù ed $\emptyset$ has cha saviu tener; ed ussa enqueres ti da pigiar mei; ... (Decurtins 1880-1883: 274, lines 5-6)

'You me.CL have had and (me.ø) have not manage to-keep; and now you are trying to detain me.TON; ...'

(b) ... che jau pos mei bucca gidar ... (Decurtins 1880-1883: 287, line 1)

'...that I can me.TON not help (i.e. myself)...'

(c) ... Miu Bab, nua haveis laschau mei aschì persuls? (Decurtins 1880-1883: 295, line 9)

'...my Father, where have you left me.TON so alone?'

(d) ... Ei glei in denter vus, che mi veng ad entardir, a vender als Giedius, ...

(Decurtins 1880-1883: 268, line 33)

'...There is one among you, who me.CL comes to betray, to-sell to-the Jews, $\ldots ’$

The same is seen for the second person: tei, although morphologically a seemingly tonic form, can occupy the immediately pre-verbal position on a par with $t i$ (31a and b) as well as its expected, post-verbal canonical object position as in (31c): ${ }^{23}$

(31) (a) ... O Soing Bab! jau ti rog, che ti veglies laschar vegnir cun tei en il desiert a far penetienzia (Decurtins 1880-1883: 274, line 27)

'...O Holy Father! I you.CL beg, that you may-want to-let (me.ø) to-come with you in the desert to-do penitence'.

(b) ... E Giosafat di: Jau tei rog, che ti veglies ira a domendar la lubienscha dadel. 
(Decurtins 1880-1883: 261, line 28)

‘... And Giosafat says: I you.TON beg, that you may-want to-go to ask the permission from-him.'

(c) ... ad aschia rog jau tei per mia amur, ... (Decurtins 1880-1883: 260, line 38)

'... and so beg I you.TON for my love (i.e. in the name of (your) love for me).'

There are no attestations of clitics for the third person, and the tonic form is used for [+animate] referents. For [-animate] referents, we find demonstratives and abundant use of gaps, as in the following passage, in which ina pedra custeivla 'a precious stone', once introduced in the discourse, is referred to by means of a gap:

... E Barlaam gli ha respondiu: Perquei vi jau plidar cun el; jau sun in mercadon, che veng de tiarras jastras, ed hai portau cau ina pedra custeivla, la qualla ha quella vertit, che tgi che $\emptyset$ porta sur sesez cun bien cor, veng mai a murir, e sche el fuss ciogs u leprus u schiraus u zops u autras malatias, sche daventa el bein gleiti sauns e fresgs; ed aschia $\emptyset$ porta jau a tiu Segniur Giosafat, pertgiei jau sai che el ha da basengs; aber sapias, che sche ti mi $\emptyset$ laies bucca portar a tiu Signiur Giosafat, sche $\emptyset$ porta jau tier in auter grond Signiur, il qual veng a comprar $\emptyset$ per in grond scazi. Cura che il Portner ha giu entelleig il mercadon, che el vessi ina pedra pretiusa da tonta vertit ha el deg: Jau ti roga, che ti mi ø veglias laschar ver; a schi mi $\emptyset$ mussas, sche empermetta jau de laschar ira en il Pallaz a plidar cun miu Segniur. E Barlaam ha replicau: Jau vi bucca far quei, pertgiei glei bucca raschun, che ti $\emptyset$ vesias avon tiu Segniur, e lura era po bucca ver $\emptyset$ persuna de quest mund, sche el ei bucca 
purschals; adaschia non essent ti purschals, poss per quei bucca ver $\emptyset$. Aber a tiu Segniur Giosafat, che ei purschals, vi jau mussar ø. ... (Decurtins 1880-1883: 265, lines 5-21)

'And Barlaam to-him.CL has answered: For-this-reason I want to-talk with him.TON; I am a merchant, who comes from foreign lands, and I-have brought here a precious stone, that has that power, that who that it.ø carries on himself with a good heart, comes never to die, and if he were blind or leprous or lame or (with) other ilnesses, so (he) (would) become instantly healthy and fresh; and so it.ø bring I to your lord Giosafat, as I know that he has of need (i.e. he needs it); but be-warned, that if you me itø let not to-take to your lord Giosafat, so it.ø take I to another lord, who comes to-buy it.ø for a great amount of money. When the door keeper has heard the merchant, that he had a precious stone of such powers has he said: I you.cl beg, that you me it.ø may-want to-let to-see; if you to-me.CL it.ø show, so promise I to let you.Ø to-go inside the palace to speak with my lord. And Barlaam has answered: I want not to-do this, because there is no reason, that you it. $\varnothing$ see before your lord; and then not to-see it.ø person of this world, if he is not pure (i.e. and nobody in this world can see it unless they are pure); and so not being you pure, can for this (reason) not to-see it.ø (i.e. and you, not being pure, you cannot see it). But to your lord Giosafat, who is pure, want I to-show it.ø.'

It is immediately apparent that gaps are best attested with third person singular [animate] referents, suggesting that this is the first form to be lost, followed by [+animate] for which tonic forms are used, in turn followed by third person plural. First and second 
person singular are mainly realised by clitic forms (or else by morphological tonic forms that seem to behave like clitics, i.e. weak forms), with a few attestations of gaps. No definite conclusions can be drawn for first and second plural, due to the scarcity of evidence. Mapping the information along a diachronic sequence, a partial hierarchy of loss based on person features can be formulated for Surselvan:

$$
3^{\text {rd }} \mathrm{sg}[- \text { anim }>+ \text { anim }]>3^{\text {rd }} \mathrm{pl}[?-\text { anim }>+ \text { anim }]>1^{\text {st }}, 2^{\text {nd }} \mathrm{sg}
$$

This partial hierarchy is almost identical to the one identified for the Comelico varieties (except for first person plural), repeated here:

$$
3^{\text {rd }} \mathrm{sg}[- \text { anim }>+ \text { anim }]>3^{\text {rd }} \mathrm{pl}[- \text { anim }>+ \text { anim }]>1^{\text {st }}, 2^{\text {nd }} \mathrm{sg}>2^{\text {nd }} \mathrm{pl}
$$

It is interesting that in Surselvan there does not seem to be evidence of gaps allowed to express first person plural: this clearly indicates that in this case, the hierarchy third > first and second is operative, and the loss of first person plural is not as advanced. A similar result is also offered by The Diary, in which the abundance of first person plural forms allows for significant observations: clitics are clearly dominant, followed by gaps in the dative, indicating that first person plural is not at the forefront in the process of loss.

Finally, in Surselvan too, and to an even larger extent than in Comelico, we can witness a weakening of tonic forms that end up being much more flexible in their usage, and a gradual giving way of the clitic forms to gaps. Bearing in mind that Surselvan represents the complete process of clitic loss, we are now in a position to offer a fuller view of the 
stages of clitic loss.

(34) (a) First stage: clear division of labour between tonic and clitic forms;

(b) Second stage: tonic and clitic forms are in free variation; tonic pronouns still occupy the canonical post-verbal position (in the Comelico varieties) or can occur pre-verbally (in Surselvan), hence showing syntactic weakening; no contrastive interpretation necessarily associated with tonic form usage;

(c) Third stage: gaps are introduced and used alongside clitics and/or tonic/weak forms;

(d) Fourth stage: tonic/weak forms prevail over clitic, gaps increase in frequency;

(e) Fifth stage: gaps are preferred;

(f) Sixth stage: tonic forms are re-introduced (modern Surselvan), the cycle begins again?

\subsection{Brazilian Portuguese and Contemporary French}

As already mentioned, modern BP has a defective object clitic paradigm in that the third person seems to have disappeared completely, and can be either expressed by a null form (i.e. a null object) or by a tonic pronoun, the choice between the two being determined by the semantic properties of the antecedent. A null object must be at least one of a) [animate], b) [-specific]. This is a change that has happened over the last few centuries: a diachronic study of plays written between the $16^{\text {th }}$ and the $20^{\text {th }}$ century (Cyrino 1997) has revealed a decrease in the realisation of a third person direct object as a clitic from $89 \%$ in the $16^{\text {th }}$ century to $21 \%$ in the $20^{\text {th }}$ century. The first null object to appear referred to a proposition, i.e. it had a third person, non referential antecedent. This was followed by a 
null object that referred to a referential, [-animate] element, i.e. third person, referential and inanimate. Clearly, the process of loss has been driven by features such as referentiality, animacy as well as person, with animacy and person playing the main roles.

Although not classified among the null-object languages, French has been revealed, through increasing corpus-based research (see Fónagy 1985; Lambrecht \& Lemoine 2005, among others), to allow the null realisation of referential direct objects:

(35) (a) A: J'ai un truc pour toi si ça t'intéresse.

'I have something for you if you are interested'.

B: C'est quoi?

'What is it?'

A: Je crois que t'aimes bien, toi, ce genre de truc. J'ai trouvé hier.

'I think that you like this sort of thing. I found it. $\varnothing$ yesterday.'

(from Lambrecht \& Lemoine 1996: 297)

(b) Un jour, je me disais, je mettrais une petite annonce dans Le Provençal: [...] Mais je renvoyais toujours à plus tard.

'One day, I told myself, I would put a classified ad in Le Provençal: [...] But I kept putting it.ø off until later.'

(from Larjavaara 2000: 63)

Albeit strongly stigmatized, this construction is fully productive in both written and spoken French and it is constrained by pragmatic, discursive, and stylistic factors (see Cummins \& Roberge 2005; Lambrecht \& Lemoine 2005). The null realization of the object 
is favoured by a number of factors, which include person and animacy of the antecedent: third person, [-human] referents are those that are expressed as null objects the most frequently.

Is French on its way to becoming a null object language? At this stage it is not possible to say: interestingly, however, French is not alone in displaying this property, and, once again, it is the third person that undergoes the process first. ${ }^{24}$

All the evidence discussed in this section unanimously identifies third person as the first targeted by a process of loss, an indication that the unusual pattern witnessed in Comelico, with first plural being the cell that is most widely missing, may not be a result of the same process of clitic loss that is affecting the rest of the paradigm. At this stage we are not in a position to identify the exact reason behind this; more research, especially cross-linguistic, is needed.

The next section turns to the possible interpretation of the links between the processes of emergence and loss.

\section{LANGUAGE CHANGE, HIERARCHIES AND UNIVERSAL LAWS}

The person hierarchy of clitic loss suggested for the Comelico varieties seems to follow the same path as the attested case of clitic loss in Surselvan, as well as what seen so far for BP and French. ${ }^{25}$ In all cases it is the third person which is affected first by the process of loss, with [-animate] referents preceding [+animate] ones in the process, followed by first and second. The reconstruction of the possible developmental path followed by the Latin pronominal forms that eventually became object clitics has suggested that first and second person pronouns had the potential to display clitic behaviour much earlier than the forms 
used for third person. There does not seem to be an indication that a clitic form was used earlier for [+animate] than for [-animate] referents: in the Parody of the Lex Salica example discussed above, the clitic pronoun resumes a [-animate] referent, ipsa cuppa 'the cup', underlined in (36):

... et ipsa cuppa frangant la tota...

'... and the cup, may they break it completely...'

(from Wanner 1987: 88)

Focusing on the person specification only, it therefore seems that the two developmental paths, emergence and loss, operate along the same hierarchy but in opposite directions: in the process of emergence the first and second person develop first, followed by the third; in the process of loss the third is lost first, followed by first and second.

The foregoing is reminiscent of a parallel already observed by Jakobson (1941/1968) between language development (i.e. first language acquisition) and language dissolution (i.e. aphasia): the last elements to have been acquired were lost first (1968: 92). On this basis Jakobson formulated a principle for language change, the so-called laws of irreversible solidarity:

'... one cannot erect the superstructure without having provided the foundation nor can one remove the foundation without having removed the superstructure.... The linguistic progress of the child and the regression of the aphasic are, in essence, direct and particularly concrete consequences of this principle. The STRATIFIED STRUCTURE OF LANGUAGE [SP emphasis] is in this way revealed.' 
Although his evidence was largely phonological, he also assumed that this principle would hold for other linguistic levels.

Jakobson's laws have served as the basis for the recapitulation (i.e. parallels between language diachrony and language acquisition) and the regression (i.e. parallels between language acquisition and language loss) hypotheses. They have also found expression in computing science under the name of LIFO, 'Last In First Out', an abstract principle used in list processing and temporary storage. A LIFO structure can be illustrated with the example of a stack of cards: the last card to be placed on top is also the first to be removed or evaluated. Indeed the same principle has also been found to determine performance in naming tasks in cases of language deterioration: just to mention two, for both elderly (Hodgson \& Ellis 1998) and clinical informants who had undergone anterior temporal labectomy (Bell et al. 2000) those lexical items that had been acquired last were also the first ones to be lost.

Although a last in first out principle makes intuitive sense in those cases that involve memory/storage of lexical items, there does not seem to be an immediately corresponding parallel with the cases of loss/emergence discussed in this paper. The dynamics of such a change show that it is not a simple matter of having 'lost' the word for a given clitic: the process is more complex than that, and involves morpho-syntactic re-analysis of pronominal forms. Yet, the fact that both processes of emergence and loss seem to be following the same path, albeit in reverse order, cannot be just coincidental. This makes sense when taking Jakobson's laws of irreversible solidarity as strictly dependent on (or even the result of) the 'stratified structure of language': they are the visible expression of the internal organisation of language, which is structured by and organised around more 
general principles such as markedness, or putative language universals. In other words, Jakobson's principle is the by-product of the workings of more general hierarchies operative in language.

Cyrino, Duarte \& Kato (2000) observe that BP is undergoing two processes: on the one hand, it is gradually becoming a non-null subject language, on the other, a null object language. Although no link is claimed by the authors to exist between the two, it is clear that both have been/are being guided by the same hierarchy, followed in opposite directions: the Referential Hierarchy (RH henceforth, Silverstein 1976; Comrie 1981 among others). The more referential items (i.e. [+human] and [+specific]) are the first to become phonetically realised subject; the less referential ones (e.g. expletive pronouns such as there) are still null. Conversely, the less referential objects are almost categorically not expressed, i.e. null. ${ }^{26}$

Referential hierarchies are a standard way of capturing limitations on the morphosyntactic behaviour of arguments. The cross-linguistic restrictions on the distribution of noun phrases, clitic and tonic pronouns indicate that referentiality is highly relevant for pronominalization, as well as for the overt or null realization of forms for those languages that allow for the variation. Referentiality is the result of the interplay of a number of features: argumenthood, nature of the nominal phrase, person, animacy, referentiality (understood as the ability or lack of ability to have a referent in the real world) and specificity: the interaction of these properties creates a scale against which linguistic items are evaluated and around which they are organised, the RH. At the lower end, there are non-specific, non referential, inanimate elements; at the higher end, specific, referential, human elements. Being intrinsically human (and definite), first and second person pronouns 
score higher than third person and are considered as 'marked'; within third person, items that are [-human] naturally score lower than [+human] and are the most 'unmarked' forms. ${ }^{27}$ It is undeniable that markedness expresses something of linguistic relevance, in spite of the many features that have been claimed to determine it. It seems that it is possibly best interpreted in terms of a hierarchy organised along increasing and decreasing values of a given property. ${ }^{28}$

Referential hierarchies in particular, but hierarchies in general, are the focus of increasing attention by linguists: preliminary neurolinguistic evidence shows that referential hierarchies play a key role in language processing (see Philipp et al. 2008, Wang et al. 2009), suggesting that they may hold the key to universal aspects of human cognition. There are a number of questions regarding both the nature and structure of referential hierarchies that still await an answer. For example, are they to be taken as probabilistic or universal? Is there one universal scale or are there several? Do these hierarchies affect all kinds of grammatical relations or do they only apply to selected morpho-syntactic categories, and if so what determines the choice? Why do referential hierarchies exist in the first place? The increasing amount of research on an ever wider number of languages will undoubtedly cast light on these issues: for the time being it is interesting to notice that referential hierarchies do exist and their effects are far-reaching.

\section{CONCLUSIONS}

This study has investigated defective paradigms of object clitics in a number of neighbouring Italian dialects, and has compared it to the process of emergence of pronominal clitics in proto-Romance, as well as to established cases of clitic loss, Surselvan 
and Brazilian Portuguese. In spite of its limitations, among them the unavailability of (reliable) diachronic sources to plot the precise steps of clitic loss in the Comelico varieties, and the complexity and heterogeneous nature of the evidence from Latin and protoRomance, this research has identified a link between the process of clitic emergence and clitic loss. The relationship between the two processes has been discussed in relation to Jakobson's structuralist approach and the Referential Hierarchy: it seems that the former may simply be a by-product of a well-identified hierarchy in cases of language change. It is clear that in order to provide a testing ground for the suggestions made in this article as well as a deeper understanding of the nature and properties of hierarchies more research is needed. In particular, a comparison of the diachronic development with the process of acquisition of clitics in children acquiring their first language may prove particularly insightful, as well as a widening of the languages included in the investigation to offer a more comprehensive, typological comparison. 


\section{REFERENCES}

Atlante Italo-Svizzero, 1928-1940. Sprach und Sachatlas Italiens und der Südschweiz, von Karl Jaberg und Jakob Jud.

Ascoli, Graziadio Isaia 1880-1888. ‘Annotazioni sistematiche al Barlaam e Giosafat soprasilvano. Saggio di morfologia e lessicologia soprasilvana.' Archivio Glottologico Italiano 7, 406-612.

Azevedo, Milton M. 2005. Portuguese: A Linguistic Introduction. Cambridge: Cambridge University Press.

Bell, Brian D., Keith G. Davies, Bruce P. Hermann \& Gina Walters. 2000. Confrontation naming after anterior temporal lobectomy is related to age of acquisition of the object names. Neuropsychologia 38, 83-92.

Benincà, Paola \& Cecilia Poletto. 2005. On some descriptive generalizations in Romance. In Richard S. Kayne \& Guglielmo Cinque (eds.), The Oxford handbook of comparative syntax, 221-258. New York \& Oxford: Oxford University Press.

Benincà, Paola \& Cecilia Poletto. 2005a. The third dimension of person features. In Leonie Cornips \& Karen P. Corrigan (eds.), Syntax and variation: Reconciling the biological and the social, 265-299.Amsterdam/Philadelphia: John Benjamins.

Benveniste, Emile. 1971. Problems in General Linguistics. Coral Gables, Florida: University of Miami Press.

Cardinaletti, Anna \& Michal Starke. 1999. The typology of structural deficiency: A case study of the three classes of pronouns. In Henk van Riemsdijk (ed.), Clitics in the Languages of Europe, 145-233. Berlin \& New York: Mouton de Gruyter.

Chafe, Wallace. 1994. Discourse, Consciousness and Time: The Flow and Displacement of 
Conscious Experience in Speaking and Writing. Chicago \& London: The University of Chicago Press.

Cyrino, Sonia. 1997. O objeto nulo no português do Brasil - um estudo sintáticodiacrônico. Londrina, Editora da UEL.

Cyrino, Sonia, M. Eugênia L. Duarte \& Mary A. Kato. 2000. Visible subjects and invisible clitics in Brazilian Portuguese. In Mary A. Kato \& Esmeralda Vailati Negrão (eds.), Brazilian Portuguese and the Null Subject Parameter, 55-73. Vervuert \& Madrid: Iberoamericana.

Comrie, Bernard. 1981. Language universals and linguistic typology. Chicago: University of Chicago Press.

Cummins, Sarah \& Yves Roberge. 2005. A modular account of null objects in French. Syntax 8, 44-64.

Decurtins, Caspar (ed.). 1880-1883. Quattro testi soprasilvani. Archivio Glottologico Italiano 7, 151-364.

Duarte, M. Eugênia L. 1989. Clítico acusativo, pronome lexical e categoria vazia no Português do Brasil. In Fernando Tarallo (ed.), Fotografias Sociolingüísticas, 19-34. São Paulo: SP. Pontes.

Egerland, Verner \& Anna Cardinaletti. 2010. I pronomi personali e riflessivi. In Lorenzo Renzi \& Giampaolo Salvi (eds.), Grammatica dell'italiano antico, vol. II, 401-467. Bologna: Il Mulino.

Fabbiani, Giovanni. 1964-5. Notizie sul notariato cadorino. Rassegna Economica XII.6 (1964), 12-24, XIII.1 and 2 (1965), 34-52 and 7-21.

Farrell, Patrick. 1990. Null objects in Brazilian Portuguese. Natural Language \& Linguistic 
Theory 8.3, 325-346.

Fónagy, Ivan. 1985. J'aime, je connais: Verbes transitifs à objet latent. Revue Romane 20, $3-35$.

Forchheimer, Paul. 1953. The category of person in language. Berlin: Walter de Gruyter.

Galves, Charlotte. 2000. Agreement, predication and pronouns in the history of Portuguese. In João Costa (ed.), Portuguese syntax: New comparative studies, 143-168. New York \& Oxford: Oxford University Press.

Haiman, John \& Paola Benincà. 1992. The Rhaeto Romance languages. London: Routledge.

Harley, Heidi \& Elizabeth Ritter. 2002. Person and number in pronouns: A featuregeometric analysis. Language 78.3, 482-526.

Hodgson, Catherine \& Andrew Ellis. 1998. Last in, first to go: Age of acquisition and naming in the elderly. Brain and Language 64, 146-163.

Jakobson, Roman. 1941. Kindersprache, Aphasie und allgemeine Lautgesetze.

Jakobson, Roman. 1968. Child language and aphasia. (English translation of Jakobson 1941). The Hague: Mouton.

Kayne, Richard S. 1975. French syntax: The transformational cycle. MIT Press.

Kaiser, Georg \& Franziska M. Hack. (forthcoming). Language change in comparison: The (special) case of Raeto-Romance. In Jürg Fleischer \& Horst Simon (eds.), Comparing diachronies. Sprachwandelvergleigh. Berlin: de Gruyter.

Lambrecht, Knud \& Kevin Lemoine. 2005. Definite null objects in (spoken) French: A construction-grammar account. In Mirjam Fried \& Hans C. Boas (eds.), Grammatical constructions: Back to the roots, 13-55. Amsterdam/Philadelphia: Benjamins. 
Lindsay, Wallace. 1891. Latin accentuation (Concluded). The Classical Review 5.9, 402 408.

Larjavaara, Meri. 2000. Présence ou absence de l'objet: Limites du possible en français contemporain. Helsinki: Academia Scientiarum Fennica. http://ethesis.helsinki.fi/julkaisut/hum/romaa/vk/larjavaara/presence.pdf.

Lucchesi, Dante \& Tânia Lobo. 1996. Aspectos da sintaxe do Português Brasileiro. In Isabel Hub Faria, Emília Ribeiro Pedro, Inês Duarte \& Carols A. M. Gouveia (eds.), Introdução à lingüística geral e portuguesa, 303-322. Lisboa: Caminho.

Maiden, Martin, Smith, John Charles \& Adam Ledgeway. 2011. Introduction. In Martin Maiden, John Charles Smith \& Adam Ledgeway (eds.), The Cambridge history of the Romance languages, xxi-xxii. Cambridge: Cambridge University Press.

Martini, Giobatta 1870 circa. La Passion del nos Signor Gesù Cristu scritta da San Mattiu in lenghe d'Padle. In Tagliavini, 1932.

Paoli, Sandra. 2009. Gerarchie di caso e persona nei paradigmi dei pronomi atoni obliqui: Il caso dei dialetti del Comelico. Rivista Italiana di Dialettologia 33, 59-84.

Pescarini, Diego. 2009. The evolution of the determiner $e l$ in Veronese. Paper presented at the IX Incontro di dialettologia, Bristol, $6^{\text {th }}-7^{\text {th }}$ March 2009.

Philipp, Markus, Ina Bornkessel-Schlesewsky, Walter Bisang \& Matthias Schlesewsky. 2008. The role of animacy in the real time comprehension of Mandarin Chinese: Evidence from auditory event-related brain potentials. Brain and Language 105, 112 133.

Poletto, Cecilia. 2012. Contrastive linguistics and micro-variation: The role of dialectology. Languages in Contrast 12.1, 47-68. 
Priscian. Grammatici latini: Ex recensione Henrici Keilii. vol. III.

http://www.archive.org/stream/grammaticilatin04hagagoog\#page/n14/mode/1up.

Rizzi, Luigi. 1986. Null objects in Italian and the theory of pro. Linguistic Inquiry 17, 501157.

Ronzon, Antonio. 1873-74. Da Pelmo a Peralba. Almanacco cadorino. Vol. I. Venezia: Tipografia Antonelli.

Salvi, Giampaolo. 2001. La nascita dei clitici romanzi. Romanische Forschungen 113.3, 285-319.

Schwan, Eduard \& Dietrich Behrens. 1913. Grammaire de l'ancien français. Leipzig: Reisland.

Siewierska, Anna. 2004. Person. Cambridge: Cambridge University Press.

Silverstein, Michael. 1976. Hierarchy of features and ergativity. In Robert M. W. Dixon (ed.), Grammatical categories in Australian languages, 112-171. Canberra: Australian Institute of Aboriginal Studies.

Tagliavini, Carlo. 1926. Il dialetto del Comelico. Archivum Romanicum X.1-2, 1-200.

Tagliavini, Carlo. 1932. Testi dialettali comelicesi del secolo scorso. Rivista Italiana di Letteratura dialettale IV.2, 109-123.

Tagliavini, Carlo. 1988. Il dialetto del Comelico. Ristampa anastatica dell'edizione del 1926, Comunità montana del Comelico e Sappada.

Vanelli, Laura. 1987. I pronomi soggetto nei dialetti italiani settentrionali dal Medio Evo a oggi. Medioevo Romanzo 12, 173-211.

Vàrvaro, Alberto. 1984. La parola nel tempo. Lingua, società e storia. Bologna: Società Editrice Il Mulino. 
Wang, Luming, Matthias Schlesewsky, Balthasar Bickel \& Ina Bornkessel-Schlesewsky. 2009. Exploring the nature of the "subject"-preference: evidence from the online comprehension of simple sentences in Mandarin Chinese. Language and Cognitive Processes 27.7-8, 1180-1226.

Wanner, Dieter. 1987. The development of Romance clitic pronouns: From Latin to old Romance. Berlin: Mouton de Gruyter.

Author's address:

Centre for Linguistics and Philology

Walton Street

Oxford

OX1 2HG, United Kingdom

\section{FOOTNOTES}

${ }^{1}$ The leave for the research presented here was funded by two grants from the John Fell Fund, reference 073/697 (Comelico) and 092/326 (Sursilvan), which are gratefully acknowledged. Part of the data presented here appeared in Paoli (2009). I am greatly indebted to my Comelico informants and to the curators of the various libraries and archives. This article is only able to contain a small part of all the materials collected, but it is hoped that it can nevertheless give a glimpse of the linguistic value of these dialects. Deep thanks also go to Giampaolo Salvi, Michele Loporcaro, Philomen Probert, Martin Maiden and Chiara Cappellaro for very helpful suggestions and bibliographical leads. The 
final version of this paper owes a great deal to the generous, perceptive and thoughtprovoking comments of four anonymous $J L$ reviewers. All errors remain, needless to say, my own responsibility.

${ }^{2}$ The Atlante Italo-Svizzero 'Italo-Swiss Atlas' is a linguistic atlas reporting the dialect variants of a number of lexical items as used throughout Italy and Southern Switzerland. It consists of geographic tables in which each location is represented by a numbered point. ${ }^{3}$ Throughout the article the glosses are simplified and focus on the type of pronoun used. Hence only the following abbreviations are used: CL 'clitic/atonic pronoun', TON 'tonic pronoun', WEAK 'weak pronoun', $\varnothing$ 'no pronoun used', SCL 'subject clitic', FEM 'feminine', NEG 'negation'. For simplicity the ' $\varnothing$ ' symbol is placed where a clitic form would be expected: this seems to be reasonable given that all the varieties have tonic forms, and a non realized form is certain to be a (missing) clitic. In the tables, a distinction is drawn between two cases: when the atonic form does not exist at all for a given cell the '-' symbol is used; when an atonic form exists but it is subject to distributional constraints (e.g. restricted to [+animate] referents), its absence is indicated with ZR 'zero realization'. ${ }^{4}$ It is of interest that the AIS data were obtained through the translation of a list of sentences written in Italian: in the original sentence the clitics are present (as in $\left(1 c^{\prime}\right)$ and $\left(1 d^{\prime}\right)$ ), and the R-R speakers are explicitly not introducing them in spite of the model. ${ }^{5}$ Lhe has now come to function in $\mathrm{BP}$ as a second person clitic, both for the dative and the accusative.

${ }^{6}$ The term 'dialect' needs a note of clarification: the Italian dialects are not dialects OF Italian, but sister languages of Italian, with Latin as the common ancestor. 
${ }^{7}$ An anonymous reviewer suggests that seemingly clitic pronouns in the Comelico varieties could in fact not be clitic, but weak forms. In order not to gloss over this possible and significant difference, they are referred to as 'atonic' until Section 3.1, in which their status is clarified. However, they are glossed as CL all along.

${ }^{8}$ Incidentally, Poletto (2012: 49ff) claims that there is no qualitative difference between macro- and micro-variation, hence bringing typological and dialectal variation on the same level as far as the observation of potential language universals is concerned.

${ }^{9}$ Regional Italian, simplistically defined as the result of the influence of the local dialect on Standard Italian, is also of interest as it reflects underlying dialect usage.

${ }^{10}$ It is possible that the restriction is more specific than [+animate], i.e. [+human], but at present we have no access to data that could answer this. The reference will therefore be to animacy.

${ }^{11}$ As all Northern Italian and Tuscan dialects, the variaties under investigation also have a set of weak pronominal subject forms, so-called subject clitics, which are found in both declarative and interrogative finite clauses. The paradigms are incomplete for all of them, and the forms that exist are summarised in Table $\mathrm{i}$ and glossed as 'SCL' in the examples: <Insert Table i about here>

12 The past participial forms in Padola and Candide are subject to the elision of the final vowel, hence both vist and vistu 'seen' are found, as in example (4). This alternation seems to be due to prosodic factors such as phrasing, but at present we are unable to be more specific.

${ }^{13}$ Sentential negation in Padola takes the form of $n(e)$ : 
(i) Nclote zla purzision $\mathbf{n}$ pudé misiasi omi e femni.

in-those-days in-the procession NEG could mix men and women

'In those days, men and women could not mix in the processions.'

A special form, ne n', is used with those forms of the verbs avè 'to have' and ési 'to be' that begin in a vowel (see (ii) and (iii)); with all other forms of these two verbs (see (iv)) only $n e$ is found:

(ii) Ne n' à maió.

NEG NEG has snowed

'It has not snowed.'

(iii) Li tov' ne n' ere li primi, ... the yours NEG NEG were the first

'Yours were not the first, ...'

(iv) Ne sèi siguru.

NEG am sure

'I'm not sure.'

This is clearly not a partitive clitic (which does not exist in this variety), as the following example, where no possible underlying partitive meaning can be inferred, shows:

(v) Ne n' é 'l soltu amór e sentimentu,...

NEG NEGis the usual love and feeling

'It is not the usual love and feeling, ...'

The same form, ne n', is also found, under the same conditions, in San Nicolò.

${ }^{14}$ In Comelico the local dialects are officially introduced in the drawing up of legal 
documents as early as 1631 (see Fabbiani 1964-5), but the evidence is seldom forthcoming, as the specific legal writing style favours the repetition of the whole noun phrase rather than its replacement with a pronominal form. For the dialect of Padola, there is a text dating from around 1870, The Passion according to Saint Matthew, translated from (possibly) Italian by Martini. From around the same period there are also a number of sonetti in the dialects of Candide and San Nicolò, collected in Ronzon (1873-74). Tagliavini himself (1926) offers a collection of 27 texts in the various Comelico dialects to which he adds (1932) another 3. In all of the above it is possible to find atonic forms for third person singular and plural accusative, and occasionally (but inconsistently) for third person singular dative, which display clitic-like behaviour in their syntactic position and pragmatic non-salience.

${ }^{15}$ The dialect of Costalta, included in this research for purposes of comparison, has often been described as 'conservative', in that it has preserved archaic words that have long disappeared from the other dialects (see Tagliavini 1926: 15). Interestingly, Costalta is also the dialect that has a full set of atonic pronouns. If this were also to be interpreted as an archaic feature, it would represent further support for the decay hypothesis.

${ }^{16}$ Due to the poverty of reliable diachronic data, this second hypothesis cannot be tested.

${ }^{17}$ The term 'proto-Romance' is used to refer to that elusive stage between Latin and the Romance languages; although clearly not precise, it is adopted in order to avoid the controversial labels of 'late Latin' or 'Vulgar Latin' (see also Maiden, Smith \& Ledgeway (2011: xxi-xxii)).

${ }^{18}$ Not to mention the tension between written and spoken language, which clearly grew 
wider and wider: the observations made here are based on written evidence, but it seems reasonable to assume that the same reasoning would also hold for the spoken language.

${ }^{19}$ As shown in Section 5.1, the use of demonstratives in lieu of personal pronouns is a widely-employed alternative historically as well as synchronically. According to Forchheimer (1953: 6) this is due to the fact that third person is unmarked, relative to the other persons, and hence can be treated differently.

${ }^{20}$ It is worth mentioning that Lindsay (1891: 404), quoting Priscian (Priscian, GL iii.141.15 Keil, p. 161, line 15-17), comments on the fact that Latin had no morphological equivalent corresponding to the Greek distinction between eîdén me and ê̂den emé 'he saw me', and yet, that distinction in Latin was clearly available, achieved possibly through intonation: apud nos autem pronomina eadem et discretiva sunt, ut 'vidit me' vel 'vidit me, illum autem non, 'but in our language the same pronouns are also contrastive (as non-contrastive), as in "he saw me" or "he saw me, but not him".

${ }^{21}$ Although it is not possible to establish undisputedly the exact origin of the R-R variety used in these texts or its level of genuineness, it is here assumed that it is Surselvan. This assumption is based on the morphological and phonological features listed by Ascoli (1880-1883: 413ff) which identify Barlaam and Josaphat as written in the Catholic variety of Surselvan, and the fact that the author of the second text, the Diary, was born and spent his whole life in the Surselvan-speaking area of Switzerland.

${ }^{22}$ As Table 11 shows, the form that follows the preposition $a$ 'to' is $m i$ rather than the tonic form $m e i$, furthermore, there exist univerbated forms for the third person (preposition+pronoun), and only with the preposition $a$. This may be a relic of the old case 
system: the retention of an inherited dative case for both pronouns and definite articles is indeed witnessed in the contemporary R-R variety of Surmeiran (Haiman \& Benincà 1992: 99), and in earlier stages to other R-R varieties. This means that cases of $m i$ following the preposition $a$ cannot be assumed to be instances of a tonic pronoun.

${ }^{23}$ Sursilvan is a V2 language, as can be seen in (31c), where the presence of the adverb aschia 'so' forces the subject jau 'I' to appear in post-verbal position. It is also interesting to compare the word orders in (31a) and (31b): both seem to respect the V2 constraint, suggesting that the status of tei 'you' in $(31 \mathrm{~b})$ is not that of a tonic pronoun as indicated in the glosses (and by its morphology), but it is clearly treated by the syntax on a par with the clitic pronoun $t i$ in (31a). Although morphologically tonic, tei is syntactically weak/clitic in this example.

${ }^{24}$ Another example, which does not seem to be as widely used as in French (and which, to my knowledge, has not been investigated yet), is Hiberno-English, in which a direct object, given its recoverability from the context, can be dropped only if it is third person, singular and [-animate]. The following is taken from a conversation at the table, after a new dish has been served:

(i) Do you like $\varnothing$ ?

${ }^{25}$ Although it seems that the dative paradigm is being targeted first in a process of loss, as both in Comelico and Surselvan, there doesn't seem to be an immediate reverse parallel in a case of emergence.

${ }^{26}$ With respect to this, Italian and Spanish seem to behave differently, in allowing null objects only if they are third person, animate and arbitrary (see Rizzi 1986), as an 
anonymous reviewer has pointed out. This seems to go against the generalisations mentioned in this article, and we do not have a solution to offer. However, we wonder whether the arbitrary interpretation may be equivalent to being [-specific], which would possibly place the referents lower on the $\mathrm{RH}$, therefore justifying their ability to be left unexpressed.

${ }^{27}$ Cross-linguistically (see Silverstein 1976, Siewierska 2004 and references therein, among many others), third person pronouns usually distinguish themselves from first and second person, which are intrinsically indexical, and whose referential value changes depending on the speaker/hearer. Benveniste (1971: 217) declares that third person should not be grouped together with first and second as it is a 'non-person', and Forchheimer (1953: 5-6) identifies a number of morphological generalizations that show how third person 'lends itself' to being treated differently from first and second precisely because of its unmarked status.

${ }^{28}$ An anonymour reviewer suggests considering feature geometries as an alternative to hierarchies to account for the facts presented in this paper. We address their remark in a footnote as it is felt that although it may prove very effective to do so when investigating a larger number of languages, for the cases discussed here hierarchies seem more adequate. Harley \& Ritter (2002)'s feature geometry breaks down pronominal expressions into their basic components: the traditional features of person, number and gender are replaced by the categories of Participant, Individuation and Class, each representing a node in the tree-like representation of pronouns. Their system has the advantage of offering a way to quantify markedness on the basis of a node-counting metric (2002: 485): the more marked a given 
feature combination is, the more nodes will be required to represent it. For each category there is a default interpretation, and an organising node with a default interpretation is considered unmarked (2002: 486): on the basis of this, third person works out to be the least marked pronoun (2002: 490). However, an investigation of the (first language) acquisition of the order of pronouns in a number of languages reveals that it is either first or third person singular that are acquired first, which is determined by the 'default' status of these forms (in other words, 'default' are acquired first). 'Default' is interpreted as being supplied by Universal Grammar in terms of values for given nodes, the result of such a representation being that first and third singular are equally likely to be the first acquired pronominal form. This outcome is clearly desireable when accounting for the acquisition data, given the variation witnessed within the same language, but does not seem adequate to account for the data investigated in this article: first person singular figures rather low on the hierarchy of loss. What remains to be established is whether the same variation would also be witnessed when extending the investigation to cases of pronoun loss in many more languages. If not, it is not clear how a language would take the further step to select either first or third person as their least marked. Here we do not pursue further the application of a feature-geometric account because it would deserve a much more thorough and rigorous testing ground that can be offered in the limited space and data available here: it necessarily needs to be the object of further research of a typological nature. 